paying themselves they will hold the remainder in trust for the owners of the goods. The Carriers Act in no way alters this. I mean the owner of goods may say, "I will be my own insurer, and not declare the goods ;" and knowing of the floating policy he may trust to that, and in that there is no fraud. If the plaintiff insure as a trustee, he may recover. In that I see no hardship on the office who contracts with him.

HILI, J.-I am of the same opinion. The question turns entirely on the construction of the policy, and to my mind the parties have used plain words, to which we must give effect. $£ 15,000$ is declared to be the value of goods belonging to the plaintiffs and held by them in trust as carriers, but if it were intended to insure solely the plaintiffs' risk, why use the words "in trust as carriers?" The second condition rould not have rendered it necessary to insert those words. The observations of my brothers are well worthy of attention; the Company might easily have secured themselves, if they desired it, by inserting apt words; but on the words of this policy I think the plaintiff is entitled to recover, and I think the case of Waters vs. The MIonarch Life and Fire Company governs this case. Judgment for the Plaintiffs.

\title{
CRIMINAL LAW. ENGLISH CROWN CASES RESERVED.'
}

Larceny.-A finder of lost property is not guilty of larceny in appropriating it to his own use, unless at the time of the finding he had a felonious intent. Reg. vs. Christopher, 5 Jur., N. S., part 1, p. 24 in which Reg. vs. Thurborn, 2 Car. \& K. 831, was recognized and acted upon. The conviction was quashed, npon the ground that the proper question had not been left to the jury.

The prisoner and the prosecutor's wife were jointly concerned in removing certain goods of the prosecutor from his house. They were afterwards found living together in lodgings taken by the wife in her own name; the property was also found there. The jury were directed, that if they were satisfied that the prisoner and the prosecutor's wife, when they so took the 
property, went together for the purpose of having adulterous intercourse, and had afterwards effected that eriminal purpose, they ought to find the prisoner guilty. The court upheld a conviction. Reg. rs. William Berry, 5 Jur., N. S., part 1, p. 228.

But where the prisoners, in the presence and with the privity and consent of the prosecutor's wife, removed a quantity of his goods, and subsequently the wife left her husband's house without his knowledge or.assent, accompanied by one of the prisoners, who then also took with him some more of the prosecutor's property, and there was no evidence that the wife had committed adultery with either of the prisoners, or intended to do so, it was held, that, in the absence of any finding to the contrary, it must be assumed, in favor of the prisoners, that the wife was the principal in taking the goods, and therefore the prisoners were not guilty of larceny. It is not larceny if a wife take the goods of her husband; and therefore a stranger, though privy and accessory to such taking, cannot be guilty. Reg. vs. Avery and Another, 5 Jur., N. S., part 1, p. 577.

A servant employed to sell goods, and receive the money, sold some to a customer, who paid him for them. He did not enter the sale in his books, or account for the price, but concealed the transaction, and appropriated the money. It was held, that as there was an actual binding sale as between the buyer and the master, the servant was not guiliy of stealing the goods, although he was guilty of embezzling the price. Reg. vs. Betts, 5 Jur., N. S., part 1, p. 274.

In Reg. vs. Rowe, 5 Jur., N. S., part 1, p. 274 , the prisoner was indicted for stealing iron which he had taken from a canal while the canal was being cleaned. It appeared in evidence that if property so found could be identified, it was the practice of the canal company to return it to the owner, otherwise it was kept by the company. The prisover was, not in the company's employ:-Held, that the property in the irou was rightly laid in the canal company.

$\Lambda$ pawnbroker's ticket is the subject of larceny. Reg r. Morrison, 5 Jur., N. S., part 1, p. 604 .

Manslaughter.-The prisoner was a maker of fireworks, contrary to the stat. $9 \& 10$ Will. c. 7, s. 1. During his absence, and through the negligence of his servants, a fire broke out among some combustibles in his possession, which communicated with the fireworks, and caused a rocket to fly across the street and set fire to a house opposite, in which a person was burnt to death. A conviction for manslanghter was quashed. Reg. vs. Bennett, 4 Jur., N. S., part 1, p. 1088. 